\title{
Influence of Lead and Applied Singly and in Mixture with Chitosan on Tissue Accumulation of Clarias gariepinus
}

\author{
Mustafa TUNCSOY* Servet DURAN \\ Çukurova University, Faculty of Arts and Sciences, Department of Biology, 01330 Sarıçam, Adana, Türkiye
}

How to cite: How to cite: Tunçsoy, M. \& Duran, S. (2020). Influence of Lead and Applied Singly and in Mixture with Chitosan on Tissue Accumulation of Clarias gariepinus. J. Anatolian Env. and Anim. Sciences, 5(2), 173-177.

Atıf yapmak için: Tunçsoy, M. \& Duran, S. (2020). Kurşun ve Kurșun-Kitosan Karıșımının Clarias gariepinus'da doku birikimi üzerine etkileri. Anadolu Çev. ve Hay. Dergisi, 5(2), 173-177.

: https://orcid.org/0000-0001-7306-0539 (iD): https://orcid.org/0000-0002-1496-1932

\begin{abstract}
Clarias gariepinus was exposed to $1 \mathrm{ppm} \mathrm{Pb}$ singly and in mixture with $75 \mathrm{ppm}$ chitosan $(\mathrm{CT})$ and the levels of $\mathrm{Pb}$ in gill, liver, spleen, kidney and muscle tissues were determined after 1, 7 and 15 days. Lead accumulation increased in gill tissue compared to control when exposed to $\mathrm{Pb}$ alone and in mixture on $7^{\text {th }}$ day. A significant decrease, however, was observed in gill level on exposure to $\mathrm{Pb}+\mathrm{CT}$ mixture on day 15 . Exposure to $\mathrm{Pb}$ alone increased the level in liver significantly after 15 days compared to control fish. Exposure to $\mathrm{Pb}$ alone and to mixture had no effect on kidney accumulation. $\mathrm{Pb}$ accumulation increased in spleen tissue compared to control when exposed to $\mathrm{Pb}$ alone on $1^{\text {st }}$ and $7^{\text {th }}$ days, it decreased when exposed to $\mathrm{Pb}+\mathrm{CT}$ mixture at these exposure periods. Muscle $\mathrm{Pb}$ accumulation was higher in fish exposed to $\mathrm{Pb}$ only as compared to controls and in fish exposed to $\mathrm{Pb}+\mathrm{CT}$ mixture on $1^{\text {st }}$ day. The studied lead concentrations caused alterations in the metal accumulation especially gill and liver tissues. Chitosan seemed to decrease the harmful effects of $\mathrm{Pb}$ on long term exposures.
\end{abstract}

Keywords: Accumulation, Clarias gariepinus, chitosan, lead, mixture.

\section{Kurşun ve Kurşun-Kitosan Karışımının Clarias gariepinus'da doku birikimi üzerine etkileri}

*Sorumlu yazar:

Mustafa TUNÇSOY

Çukurova Üniversitesi, Fen-Edebiyat

Fakültesi, Biyoloji Bölümü 01330 Sarıçam,

Adana, Türkiye.

凶: mustafa_tuncsoy@hotmail.com

Mobile telephone : $+90(539) 8152828$
Öz: Bu araştırmada 1 ppm kurşunun tek başına ve 75 ppm kitosan ile karışımlarının 1, 7 ve 15 günlük etki sürelerinde $C$. gariepinus 'un solungaç, karaciğer, böbrek, dalak ve kas dokularındaki metal birikiminin belirlenmesi amaçlanmıştır. Kurşunun tek başına ve karışımın 7 günlük etki süresinde solungaç dokusunda biriktiği belirlenmiştir. Karışımın 15 günlük etki süresinde ise solungaç dokusundaki kurşun birikimi azalmıştır. Kurşunun tek başına 15 günlük süreyle etkisinde karaciğerde birikim artış göstermiştir. Böbrek dokusunda kurşunun tek başına ve karışımın etkisinde birikim gözlenmemiştir. Dalak dokusunda kurşunun tek başına 1 ve 7 günlük etki süresindeki kurşun birikimi artış gösterirken, karışımın aynı sürelerle etkisindeki birikim düşüş göstermiştir. Kas dokusunda ise kurşunun tek başına ve karışımın etkisinde yalnızca 1 günlük etki süresinde birikim gözlenmiştir. İncelenen kurşun derişimleri özellikle solungaç ve karaciğer dokusunda birikme neden olmuş, kitosanın uzun süreli etkisi kurşun birikimini azaltmıştır.

Anahtar kelimeler: Birikim, Clarias gariepinus, karıșım, kitosan, kurșun. 


\section{INTRODUCTION}

Lead $(\mathrm{Pb})$ has physical and chemical properties that make it extremely useful in various industries such as lead battery production and colored inks and paint preparation. Discharge of $\mathrm{Pb}$ containing urban, agricultural and industrial waste waters to aquatic environments result in a number of physiological and biochemical disturbances to organisms living in these environments. (Shaw et. al., 2006; Kusemiju et al., 2012). Pb have no biological function and is toxic even at very low concentrations. It is a potentially toxic chemical for aquatic animals such as fish and shellfish (Cicik, 2003). Chitin is a polymer of glucosamine which is found in shells or walls of invertebrates, fungi and yeasts. Chitosan (CT), an amino polysaccharide, is prepared from shellfish chitin by treatment with alkali. (Muzzarelli, 1977). CT is able to form complexes with many of the transition metals. The heavy metal-polymer complexes are believed to form as a result of dative bonding with CT (Muzzarelli, 1973). Physiological and biochemical profiles in fish and other aquatic organisms under heavy metal stress serve as important bioindicators in aquatic environment monitoring (Abbas et al., 2007; Firidin, 2019, Tunçsoy, 2019). Clarias gariepinus was chosen as an experimental fish species since the species is commonly found in streams and drainage channels of Mediterranean region, its consumption as a protein source in the region, its wide tolerance against pollutants and its habitat being under the effect of agricultural and industrial activities.

Aquatic organisms uptake the metals from water and sediment mainly via their gills and digestive track and accumulate them in various tissues. CT is well known as an excellent biosorbent for metal cation removal in nearneutral solutions because the large number of $\mathrm{NH}_{2}$ groups (Seyedi, 2013). Hence the aim of the present study was to determine metal levels in gill, liver, kidney, spleen and muscle tissues of $C$. gariepinus after exposing the animals to $1 \mathrm{ppm} \mathrm{Pb}$ and $1 \mathrm{ppm} \mathrm{Pb}+75 \mathrm{ppm} \mathrm{CT}$ over 1, 7 and 15 days.

\section{MATERIAL AND METHODS}

C. gariepinus was obtained from a private fish farm in Silifke-Mersin-Turkey. The mean length and weight of the animals were $21.9 \pm 2.5 \mathrm{~cm}$ and $73 \pm 3.11 \mathrm{~g}$ respectively. Fish were adapted to laboratory conditions for one month in glass aquaria 40x120x40 cm in height. The same sized five aquaria were used in the experiments. The first two aquaria were filled with $120 \mathrm{~L}$ of $1.0 \mathrm{ppm} \mathrm{Pb}$ and $1.0 \mathrm{ppm} \mathrm{Pb}+75 \mathrm{ppm} \mathrm{CT}$, respectively while the third one was filled with the same amount of lead-free tap water and used as control. Lead nitrate $\left(\mathrm{Pb}\left(\mathrm{NO}_{3}\right)_{2}\right)$ was used in the preparation of experimental solution and trisodium citrate $\left(\mathrm{C}_{6} \mathrm{H}_{5} \mathrm{Na}_{3} \mathrm{O}_{7} .5 \mathrm{H}_{2} \mathrm{O}\right)$ was used to prevent precipitation and adsorption of the metal. Experimental solutions were replaced daily, by serial dilution of freshly prepared 1000 ppm stock solution of the metal. $1 \%$ acetic acid was used to prepare CT stock solution (Aldrich, GR, Deacetylation C75 \%). Some physical and chemical properties of experimental water were as follows;

Temperature: $21.5 \pm 1^{\circ} \mathrm{C}$,

Total alkalinity: $305 \pm 0.5 \mathrm{mg} \mathrm{CaCO} / / \mathrm{L}$

Dissolved Oxygen: $7.01 \pm 0.6 \mathrm{mg} / \mathrm{L}$,

pH: $8.2 \pm 0.5$.

Experiments were run in triplicate being 3 fish in each replicate, hence 9 fish were placed in each aquarium totaling to 27 fish. Fish were fed once a day with readymade fish feed (Pınar, Pellet No: 2 ) at amounts of $2 \%$ of total biomass. Fish were anesthetized with MS222. They were then washed with tap water and dried with Whatman filter papers.

Three fish were removed from each aquarium at the end of 1,7 , and 15 days of exposure periods, they were washed dried and dissected for their gill, liver, spleen, kidney and muscle tissues. Tissues were placed in petri dishes after being wet weighted and were placed in a drying oven set at $150^{\circ} \mathrm{C}$ for 48 hours. Dried tissues were then transferred to experimental tubes and digested in nitric acid (Merck, 65\%) / perchloric acid (Merck, 60\%) mixture (2/1; $\mathrm{v} / \mathrm{v}$ ) at $120^{\circ} \mathrm{C}$ for three hours (Muramoto, 1983). Digested tissues were transferred to polyethylene tubes and their volumes were made up to $10 \mathrm{ml}$ with distilled water. Metal levels in tissues were determined using atomic absorption spectrophotometric techniques.

Statistical analysis of the data was carried out by Analysis of Variance and Student Newman's Procedure (SNK) using SPSS-21 statistical package program (Sokal and Rohlf, 1995).

\section{RESULTS AND DISCUSSION}

There was no mortality of fish during the experiments which was probably due to low metal concentration tested. The gills are considered as the main site of entry for the dissolved metal salts. They are sensitive to any change in water components hence serve as a good indicator of in water quality since gill filaments and lamellae provide a very large surface area for direct and continuous contact with contaminants in water (Gaber, 2007).

Metals entering from gills are firstly transferred to liver by the circulatory system, and when the carrying capacity of liver is exceeded, they are transferred and stored in metabolically active tissues, especially in kidney. Liver is a metabolically active tissue since it plays role in 
conversion of food, binding of harmful substances and in digestion of macromolecules especially lipids (Heath, 1995). When the metal binding capacity of liver is exceeded, the excess amount of metals is sent to kidneys for excretion (Hollis et al., 1999). Spleen is an important member of the body's immune and lymphatic system as well as it is a hematopoietic organ in which blood cells synthesized and stored (Tayel et al., 2008), also it acts as a filter and purifier of the blood (Garcia-Abiado et al., 2004). Exposure to $\mathrm{Pb}$ alone and mixture had no effect on kidney accumulation (Figure $1 \mathrm{C} ; \mathrm{P}>0.05$ ). $\mathrm{Pb}$ accumulation increased in spleen tissue compared to control when exposed to $\mathrm{Pb}$ alone on $1^{\text {st }}$ and $7^{\text {th }}$ days whereas its accumulation decreased with increasing periods (Figure $1 \mathrm{D} ; \mathrm{P}<0.05)$. Muscle is not an effective tissue in binding metals, it is, however, important to know metal levels in this tissue as far as food chain and human health is concerned (Duran et al., 2015). $\mathrm{Pb}$ accumulation in gill tissue exposed to $\mathrm{Pb}$ alone increased with increasing exposure periods and in mixture increased on $7^{\text {th }}$ day while decreased on $15^{\text {th }}$ day. Exposure to $\mathrm{Pb}$ alone increased $\mathrm{Pb}$ accumulation of $C$. gariepinus on $7^{\text {th }}$ day whereas its accumulation decreased with increasing periods (Figure $1 \mathrm{~A} ; \mathrm{P}<0.05)$. $\mathrm{Pb}$ accumulation increased in gill tissue of $C$. gariepinus compared to control when exposed to $\mathrm{Pb}$ alone on $7^{\text {th }}$ and $15^{\text {th }}$ days while decreased in this tissue exposed to mixture on $15^{\text {th }}$ day (Figure $1 \mathrm{~A} ; \mathrm{P}<0.05$ ). $\mathrm{Pb}$ accumulation increased in liver tissue compared to control when exposed to $\mathrm{Pb}$ alone on 15th day. Exposure to $\mathrm{Pb}$ alone increased $\mathrm{Pb}$ accumulation of $C$. gariepinus on 7th day whereas its accumulation decreased with increasing periods (Figure 1B; $\mathrm{P}<0.05$ ). $\mathrm{Pb}$ accumulation increased in muscle tissue of $C$. gariepinus compared to control when exposed to $\mathrm{Pb}$ alone on $1^{\text {st }}$ day while decreased in this tissue exposed to mixture at same exposure periods (Figure 1E; $\mathrm{P}<0.05)$.

Metals entering from gills are firstly transferred to liver by the circulatory system, and when the carrying capacity of liver is exceeded, they are transferred and stored in metabolically active tissues, especially in kidney. Liver is a metabolically active tissue since it plays role in conversion of food, binding of harmful substances and in digestion of macromolecules especially lipids (Heath, 1995). When the metal binding capacity of liver is exceeded, the excess amount of metals is sent to kidneys for excretion (Hollis et al., 1999). Spleen is an important member of the body's immune and lymphatic system as well as it is a hematopoietic organ in which blood cells synthesized and stored (Tayel et al., 2008), also it acts as a filter and purifier of the blood (Garcia-Abiado et al., 2004). Exposure to $\mathrm{Pb}$ alone and mixture had no effect on kidney accumulation (Figure 1C; P>0.05).
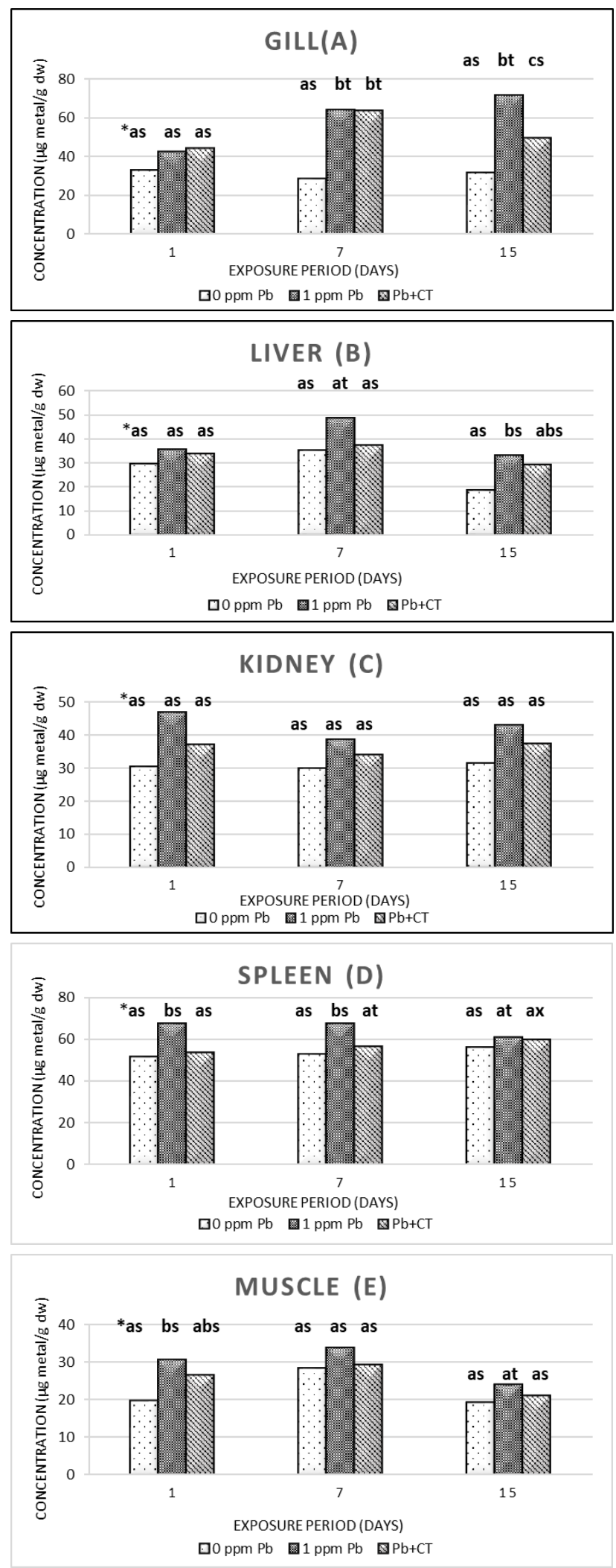

Figure 1. Lead accumulation in tissues of Clarias gariepinus exposed to $\mathrm{Pb}$ and $\mathrm{Pb}-\mathrm{CT}$ mixture ( $\mu$ g metal/g.d.w.).

*=SNK; Letters a, b, c and s, t, $\mathrm{x}$ show differences among concentrations and exposure periods at a given tissue respectively. Data shown with different letters are significant at the $\mathrm{P}<0.05$ level. 
$\mathrm{Pb}$ accumulation increased in spleen tissue compared to control when exposed to $\mathrm{Pb}$ alone on $1^{\text {st }}$ and $7^{\text {th }}$ days whereas its accumulation decreased with increasing periods (Figure 1D; $\mathrm{P}<0.05$ ). Muscle is not an effective tissue in binding metals, it is, however, important to know metal levels in this tissue as far as food chain and human health is concerned (Duran et al., 2015). $\mathrm{Pb}$ accumulation in gill tissue exposed to $\mathrm{Pb}$ alone increased with increasing exposure periods and in mixture increased on $7^{\text {th }}$ day while decreased on $15^{\text {th }}$ day. Exposure to $\mathrm{Pb}$ alone increased $\mathrm{Pb}$ accumulation of $C$. gariepinus on $7^{\text {th }}$ day whereas its accumulation decreased with increasing periods (Figure 1A; $\mathrm{P}<0.05$ ). $\mathrm{Pb}$ accumulation increased in gill tissue of $C$. gariepinus compared to control when exposed to $\mathrm{Pb}$ alone on $7^{\text {th }}$ and $15^{\text {th }}$ days while decreased in this tissue exposed to mixture on $15^{\text {th }}$ day (Figure 1A; $\mathrm{P}<0.05)$. $\mathrm{Pb}$ accumulation increased in liver tissue compared to control when exposed to $\mathrm{Pb}$ alone on 15th day. Exposure to $\mathrm{Pb}$ alone increased $\mathrm{Pb}$ accumulation of $C$. gariepinus on 7 th day whereas its accumulation decreased with increasing periods (Figure 1B; $\mathrm{P}<0.05$ ). $\mathrm{Pb}$ accumulation increased in muscle tissue of $C$. gariepinus compared to control when exposed to $\mathrm{Pb}$ alone on $1^{\text {st }}$ day while decreased in this tissue exposed to mixture at same exposure periods (Figure 1E; $\mathrm{P}<0.05$ ).

Chitosan has recently been recognized as a biopolymer with significant potential for use as biosorbent for removal of metal ions from wastewater. Dynamic and static adsorption experiments with heavy metal ions indicated that chitosan can be effectively used to adsorb these metals by establishing their different interactions with its amino and hydroxyl groups (Vieira and Beppu, 2014). Several values have predicted the trend of adsorption behavior with respect to the stability of metalbio-adsorbent complexes of $\mathrm{Pb}>\mathrm{Cu}>\mathrm{Ni}>\mathrm{Zn}>\mathrm{Cd}$ (Spostio, 1981). Pb ions are adsorbed to chitosan by coordinate and covalent linkages, ion exchange mechanisms, and electrostatic forces (Krishnamurthy and Harris, 1960). Copper-Chitosan complex increased metal accumulation in gill tissue while decreased in liver tissue of C. gariepinus (Tunçsoy et al., 2016).

Various biosorbents such as chitin and chitosan (CT) are known to form stable complexes with many metal ions. Chitin is widely distributed in nature, especially in the exoskeletons of marine invertebrates such as prawn, crab and lobster whereas its derivative CT has reactive amino groups which forms complexes between metal ions and the polymer chain. It was concluded that the studied lead concentrations caused alterations in the metal accumulation especially gill and liver tissues. Chitosan, which is a natural adsorbent, seemed to decrease the harmful effects of $\mathrm{Pb}$ on long term exposures.

\section{REFERENCES}

Abbas, H.H.H., Mahmoud, H.M. \& Miller, J.D. (2007). Vitamin $\mathrm{C}$ and Cadmium Toxicity in Fish Oreochromis niloticus. Online Journal of Veterinary Research 11, 54-74.

Cicik, B. (2003). Bakır-Çinko Etkileşiminin Sazan (Cyprinus carpio L.)'nın Karaciğer, Solungaç ve Kas Dokularındaki Metal Birikimi Üzerine Etkileri. Ekoloji, 12(48), 32-36.

Duran, S., Tunçsoy, M., Yeşilbudak, B., Ay, Ö., Cicik, B. \& Erdem, C. (2015). Metal Accumulation in Various Tissues of Clarias Gariepinus Exposed to Copper, Zinc, Cadmium and Lead Singly and in Mixture. Fresenius Environmental Bulletin. 24(12c), 4738-4742.

Firidin, G. (2019). Effects of Lead and Its Selenium Mixtures on Biochemical Parameters of Oreochromis niloticus. Fresenius Environmental Bulletin. 28(1), 383-390.

Gaber, H.S. (2007). Impact of Certain Heavy Metals on the Gill and Liver of the Nile Tilapia Oreochromis niloticus, Egyptian Journal of Aquatic Biology and Fisheries, 11, 79-100

Garcia-Abiado, M.A., Mbahinzireki, G., Rinchard, J., Lee, K.J. \& Dabrowski, K. (2004). Effect of Diets Containing Gossypol on Blood Parameters and Spleen Structure in Tilapia, Oreochromis sp., reared in a Recirculating system. Journal of Fish Diseases, 27(6), 359-368.

Heath, A.G. (1995). Water Pollution and Fish Physiology. CRC press, Florida, USA, pp. 245.

Hollis, L., Mcgeer, J.C., Mcdonald, D.G. \& Wood, C.M. (1999). Cadmium Accumulation, Gill Cd Binding, Acclimation and Physiological Effects during Long Term Sublethal Cd Exposure in Rainbow Trout. Aquatic Toxicology, 46, 101-119.

Krishnamurthy, K.V. \& Harris, G.M. (1960). The Chemistry of the Metal Oxalato Complexes. Chemical Reviews, 1, 213-246.

Kusemiju, V., Amoruwa, P. \& Aderinola, J.A. (2012). Accumulation of Lead in the Tissues of Freshwater Catfish Clarias gariepinus Exposed to Static Nominal Concentrations of Lead Nitrate. Agriculture and Biology Journal of North America, 3(12), 510-515.

Muramoto, S. (1983). Elimination of Copper from $\mathrm{Cu}$ Contaminated Fish by Long-Term Exposure to EDTA and Freshwater. Journal of Environmental Science and Health, A18 (3), 455-461.

Muzzarelli, R.A.A. (1973). Natural Chelating Polymers: Alginic Acid, Chitin and Chitosan. Pergamon, Oxford, pp. 254. 
Muzzarelli, R.A.A. (1977). Enzymatic Synthesis of Chitin and Chitosan. Occurrence of Chitin. In: Muzzarelli, R. A. A. Eds.., Chitin, Pregamon Press, New York, 5-44.

Seyedi, S.M., Anvaripour, B., Motavassel, M. \& Jadidi, N. (2013). Comparative Cadmium Adsorption from Water by Nanochitosan and Chitosan, International Journal of Engineering and Innovative Technology, 2(9), 145-148.

Shaw, J.R., Dempsey, T.D., Chen, C.Y., Hamilton, J.W. \& Folt, C.L. (2006). Comparative Toxicity of Cadmium, Zinc and Mixtures of Cadmium and Zinc to Daphnids. Environmental Toxicology and Chemistry, 25, 182-189.

Sokal, R.R. \& Rohlf, F.J. (1995). Biometry: The Principles and Practice of Statistics in Biological Research. $3^{\text {rd }}$ Edition. W.H. Freeman and Co., New York.

Sposito, G., Holtzclaw, K.M., \& LeVesque-Madore, C.S. (1981). Trace Metal Complexation by Fulvic Acid Extracted from Sewage Sludge: I. Determination of Stability Constants and Linear Correlation Analysis. Soil Science Society of America Journal, 45, 465-468.

Tayel, S.I., Yacoub, A.M. \& Mahmoud, S.A., (2008). Histopathological and Haematological Responses to Freshwater Pollution in the Nile Catfish Clarias gariepinus. Journal of Egyptian Academic Society for Environmental Development, 9(4), 43-60.

Tunçsoy, M., Duran, S., Ay Ö., Cicik, B. \& Erdem, C. (2016). Accumulation of copper in gill, liver, spleen, kidney and muscle tissues of Clarias gariepinus exposed to the metal singly and in mixture with chitosan. Bulletin of Environmental Contamination and Toxicology, 97(4), 486-489.

Tunçsoy, M., (2019). Influence of Copper Oxide Nanoparticles on Some Serum Parameters of Clarias gariepinus. Anatolian Env. and Anim. Sciences, 4(3), 387-392.

Vieira, R.S. \& Beppu, M.M. (2014). Chitosan as Adsorbent For Heavy Metal Ions: Performance and Adsorption Mechanism. In: Liam N. Robinson. (Org.). Water Resources Research Progress. Nova York: Nova Science Publishers, Inc, 149-175. 